\title{
Analisa Perbandingan Teknik Single-Pass Six- Way Blend dan Teknik Threshold Scheme Rendering Sketsa Pada Obyek Tiga Dimensi
}

\author{
Devanda S. Tamba, Wijayanti Nurul K., dan Rully Soelaiman \\ Jurusan Teknik Informatika, Fakultas Teknologi Informasi, Institut Teknologi Sepuluh Nopember (ITS) \\ Jl. Arief Rahman Hakim, Surabaya 60111 Indonesia \\ e-mail:wijayanti@if.its.ac.id, rully@is.its.ac.id, devanda.tamba12@mhs.if.its.ac.id,
}

\begin{abstract}
Abstrak-Sketsa merupakan sebuah gambar yang dibuat kasar, ringan, dan tidak memiliki banyak detail. Fokus dari pembuatan sketsa adalah penggambaran bentuk utama obyek dan pengarsiran daerah bayangan obyek. Pada saat melakukan penggambaran sketsa, penarikan garis penggambaran satu dengan lain cenderung tidak sama.

Tugas akhir ini mengimplementasikan program shader sketsa arsiran untuk obyek 3D. Pada implementasi shader, terdapat dua teknik yang digunakan, yaitu teknik Single-Pass Six-Way Blend dan teknik Threshold Scheme. Kedua teknik ini menggunakan Tonal Art Maps (TAM) untuk pembuatan efek arsiran. Perbedaannya adalah teknik Single-Pass Six-Way Blend menggunakan banyak variasi TAM lalu dilakukan proses blending, sementara teknik Threshold Scheme menggunakan sebuah TAM yang diberikan ambang batas untuk menempelkan efek arsiran pada obyek.

Program rendering sketsa arsiran pada obyek 3D telah dapat diimplementasikan menggunakan teknologi DirectX 9.0 dan IDE RenderMonkey 1.82. Kedua teknik dapat menghasilkan visualisasi sketsa arsiran pada obyek 3D. Teknik Single-Pass Six-Way Blend menghasilkan visualisasi arsiran yang lebih tebal dan gelap dibandingkan teknik Threshold Scheme. Berdasarkan hasil pengujian yang melibatkan sejumlah responden dengan menggunakan kuesioner, diperoleh hasil jika teknik Single-Pass Six-Way Blend dinilai lebih baik dibandingkan dengan teknik Threshold Scheme.
\end{abstract}

Kata Kunci-Non-photorealistic Rendering, Rendering Sketsa, Shader Programming, Tonal Art Maps.

\section{PENDAHULUAN}

$S_{\text {rim }}^{\mathrm{K}}$ KETSA merupakan sebuah gambar yang dibuat kasar, ringan, dan tidak memiliki banyak detail. Fokus utama dari pembuatan sketsa adalah penggambaran bentuk utama obyek dan pengarsiran daerah bayangan obyek. Pada saat melakukan penggambaran sketsa, penarikan garis penggambaran satu dengan lain cenderung tidak sama. Selain itu, penarikan garis arsiran sketsa bisa sejajar ataupun menumpuk bersilangan.

Di dalam grafika komputer, sketsa dapat digunakan sebagai sebuah efek rendering terhadap obyek 3D. Pembuatan rendering efek sketsa pada obyek $3 \mathrm{D}$ menggunakan konsepkonsep penggambaran sketsa pada dunia nyata [1]. Rendering efek sketsa pada obyek 3D dapat dibuat menggunakan shader tools yang dapat memberikan berbagai karakteristik obyek 3D seperti pencahayaan, pembentukan bayangan, dan tekstur.
Salah satu metode yang dapat digunakan dalam proses pembangkitan sketsa adalah metode Tonal Art Maps (TAM) [2]. TAM merupakan satu atau kumpulan beberapa tekstur arsiran yang dikomputasikan sesuai dengan karakteristik obyek 3D untuk ditempelkan pada obyek 3D.

Pada tugas akhir ini, akan dilakukan pembuatan shader sketsa arsiran yang memberikan hasil visualisasi sketsa terhadap masukan obyek 3D dengan menggunakan dua pendekatan metode TAM, yaitu Single-Pass Six-Way Blend [2] dan Threshold Scheme [3]. Shader dibuat secara dinamis agar efek sketsa dapat dibuat secara real-time sehingga ketika posisi maupun lingkungan sekitar obyek 3D dirubah maka efek sketsa akan menyesuaikan dengan perubahan tersebut dan membentuk pola sketsa arsiran yang baru.

\section{METODE RENDERING SKETSA}

Metode dalam pembuatan shader sketsa pada tugas akhir ini adalah Tonal Art Maps. Pendekatan metode yang digunakan ada dua, yaitu teknik Single-Pass Six-Way Blend dan teknik Threshold Scheme. Dalam pembuatan shader digunakan vertex shader dan pixel shader.

Pada vertex shader, kedua teknik ini memerlukan komputasi lingkungan sekitar obyek 3D seperti posisi obyek, posisi kamera, dan pencahayaan. Hasil dari komputasi lingkungan disekitar obyek 3D digunakan untuk melakukan mapping tekstur arsiran sebelum ditempelkan pada obyek 3D. Setelah komputasi pada vertex shader selesai dilakukan, hasil proses vertex shader dikirim pada pixel shader untuk dilakukan komputasi lebih lanjut. Pada pixel shader, dilakukan komputasi hasil vertex shader untuk menempelkan tekstur arsiran pada obyek 3D. Setelah itu, program shader dirender dan didapat hasil visualisasi sketsa arsiran pada obyek 3D.

\section{A. Teknik Single-Pass Six-Way Blend}

Pada teknik Single-Pass Six-Way Blend, Tonal Art Maps (TAM) yang digunakan sebanyak enam tekstur arsiran. Keenam tekstur ini memiliki perbedaan tone (gradasi terang / gelap warna setiap teksur) [4]. Masukan TAM akan digunakan pada proses penempelan tekstur hatching (arsiran). Proses dari teknik Single-Pass Six-Way Blend ditunjukkan pada Gambar 1.

Proses teknik ini dimulai dari masukan obyek 3D. Obyek ini 
diproses pada dua buah buffer, yaitu depth buffer dan normal buffer. Hasil proses buffer digunakan pada vertex shader. Pada vertex shader, proses komputasi normal pada view space, komputasi transformasi posisi, dan komputasi pencahayaan pada view space bertujuan untuk memproses faktor lingkungan di sekitar obyek 3D. Hasil proses faktor lingkungan digunakan pada proses pembobotan intensitas cahaya. Proses ini bertujuan melakukan mapping / pengelompokkan tone setiap vertex obyek 3D. Pembobotan ini menggunakan prinsip kombinasi linear convex [2] seperti Persamaan 1.

$$
\sum_{\mathrm{i}=0}^{1} \text { weight }_{\mathrm{i}, x}+\text { weight }_{\mathrm{i}_{y} y}+\text { weight }_{\mathrm{i}, y}=1
$$

Nilai dari weight / bobot pencahayaan pada setiap vertex terdiri dari weight $\mathrm{x}$, weight $\mathrm{y}$, dan weight $\mathrm{z}$. Nilai dari ketiga weight ini dikomputasikan pada perhitungan intensitas cahaya obyek 3D yang dihitung menggunakan enam rentang intensitas cahaya sesuai dengan karakteristik tone pada setiap tekstur arsiran. Sesuai dengan prinsip kombinasi linear convex, jumlah dari weight $\mathrm{x}$, weight $\mathrm{y}$, dan weight $\mathrm{z}$ pada setiap vertex harus menghasilkan jumlah bobot yang bernilai satu.

Pada pixel shader, proses penempelan tekstur hatching (arsiran) menggunakan masukan TAM disesuaikan dengan hasil mapping dari proses vertex shader. Setelah penempelan tesktur pada obyek 3D selesai kemudian dilakukan proses blending antar tekstur yang telah ditempelkan. Terakhir, didapat hasil akhir visualisasi sketsa arsiran.

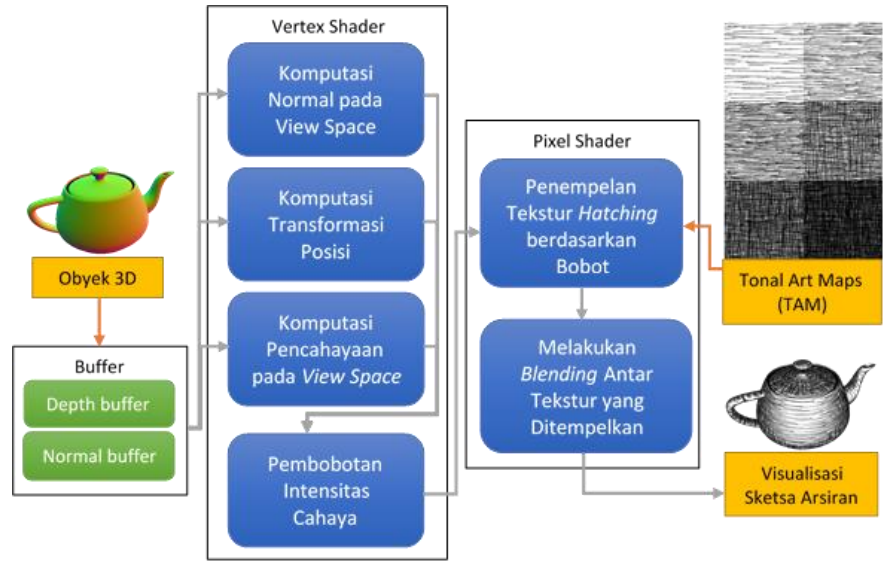

Gambar 1. Diagram Alur Proses Teknik Single-Pass Six-Way Blend

\section{B. Teknik Threshold Scheme}

Pada teknik Threshold Scheme, Tonal Art Maps (TAM) yang digunakan sejumlah satu tekstur arsiran. Tekstur ini diproses pada alpha level untuk diambil intensitas setiap garis arsiran pada tekstur [5]. Proses teknik ini memiliki garis besar yang mirip seperti teknik Single-Pass Six-Way Blend. Proses teknik Threshold Scheme ditunjukkan pada Gambar 2.

Proses teknik ini dimulai dari masukan obyek 3D. Obyek ini diproses pada dua buah buffer, yaitu depth buffer dan normal buffer. Hasil proses buffer digunakan pada vertex shader. Pada vertex shader, proses komputasi transformasi posisi, komputasi vektor cahaya, komputasi vektor posisi pada view space, komputasi transformasi normal pada view space, dan komputasi arah lihat pada view space memiliki tujuan yang sama seperti teknik sebelumnya, yaitu meproses faktor lingkungan di sekitar obyek 3D. Hasil dari proses tersebut digunakan pada proses komputasi koordinat tekstur pada obyek 3D. Proses ini bertujuan untuk mapping vertex yang disesuaikan dengan setiap garis arsiran pada satu tekstur. Untuk membuat kesan arsiran yang bersilangan dapat dilakukan translasi maupun rotasi antar garis arsiran dari satu tekstur.

Pada pixel shader, proses awal yang dilakukan adalah komputasi vektor pantulan cahaya. Setelah itu, vektor pantulan cahaya digunakan dalam komputasi ambient menggunakan Blinn-Phong. Komputasi ini bertujuan untuk menghitung intensitas cahaya pada obyek 3D. Kemudian, dilakukan penempelan tekstur arsiran pada obyek 3D sesuai dengan intensitas cahaya dan perhitungan koordinat tekstur pada proses vertex shader. Terakhir, didapat hasil akhir visualisasi sketsa arsiran.

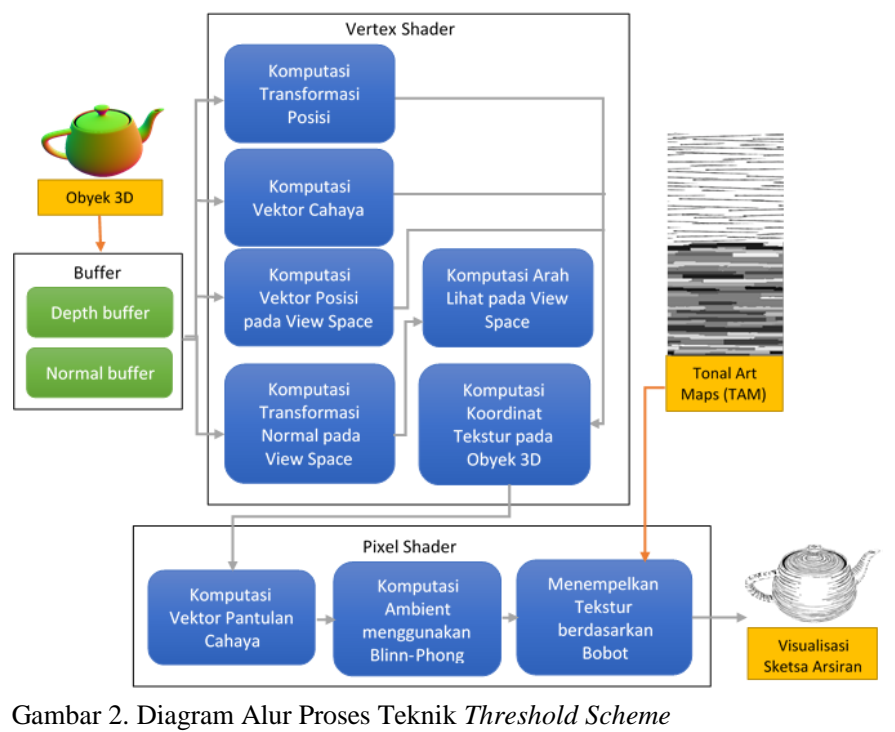

\section{UJI COBA DAN HASIL ANALISA}

\section{A. Lingkungan Uji Coba}

Uji coba dilakukan menggunakan perangkat keras Intel® Core $^{\mathrm{TM}}$ i3-CPU (3.07 GHz), RAM 4.00 GB, dan Graphic Card Intel ${ }^{\circledR}$ HD Graphics. Perangkat lunak yang digunakan adalah DirectX 9.0c SDK dan IDE RenderMonkey 1.82. Model obyek 3D yang digunakan adalah model teapot, model torus, model bunny, dan model fist. Model teapot, model torus, dan model bunny tersedia pada IDE RenderMonkey. Model fist didapat dari NTU 3D Model Database ver.1 [6]. Model ini dirender pada IDE RenderMonkey sehingga menampilkan visualisasi seperti gambar pada Lampiran.

Hasil visualisasi ini digunakan pada kuesioner untuk dinilai kualitas arsiran model obyek 3D yang telah dihasilkan. Kuesioner ini diberikan kepada sejumlah responden yang memiliki latar belakang bidang seni / desain grafis / grafika komputer. Responden dapat memberikan nilai dari skala 1 (sangat buruk) sampai skala 5 (sangat baik). 


\section{B. Hasil Uji Coba}

Pada uji coba pertama, dilakukan observasi penilaian responden terhadap visualisasi arsiran kasar teknik Single-Pass Six-Way Blend. Pada kuesioner ditampilkan gambar hasil rendering obyek teapot dan torus seperti pada Gambar 3 dan Gambar 4. Parameter yang digunakan untuk penilaian dalam kuesioner terdapat tiga, yaitu kualitas detail arsiran, kualitas arsiran dilihat dari beberapa sudut pandang, dan kualitas arsiran dilihat dari beberapa arah pencahayaan. Penilaian dari setiap parameter ini ditunjukkan pada Tabel 1.

Tabel 1.

Tabel Hasil Uji Coba 1

\begin{tabular}{lc}
\hline \hline Parameter & Modus \\
\hline Kualitas detail arsiran & 3 \\
Kualitas arsiran dilihat dari beberapa sudut pandang & 4 \\
Kualitas arsiran dilihat dari beberapa arah pencahayaan & 3 \\
\hline \hline
\end{tabular}

Pada uji coba kedua, dilakukan observasi penilaian responden terhadap visualisasi arsiran halus teknik Single-Pass Six-Way Blend. Pada kuesioner ditampilkan gambar hasil rendering obyek bunny dan fist seperti pada Gambar 5 dan Gambar 6. Kemudian digunakan tiga buah parameter seperti uji coba pertama untuk penilaian dalam kuesioner. Penilaian dari setiap parameter ditunjukkan pada Tabel 2 .

Tabel 2.

Tabel Hasil Uji Coba 2

\begin{tabular}{lc}
\hline \hline Parameter & Modus \\
\hline Kualitas detail arsiran & 4 \\
Kualitas arsiran dilihat dari beberapa sudut pandang & 4 \\
Kualitas arsiran dilihat dari beberapa arah pencahayaan & 3 \\
\hline \hline
\end{tabular}

Pada uji coba ketiga, dilakukan observasi penilaian responden terhadap visualisasi arsiran teknik Threshold Scheme. Pada kuesioner ditampilkan gambar hasil rendering obyek teapot dan torus seperti pada Gambar 7 dan Gambar 8 . Kemudian digunakan kembali ketiga parameter pada uji coba sebelumnya untuk penilaian dalam kuesioner. Penilaian dari setiap parameter ditunjukkan pada Tabel 3.

Tabel 3.

Tabel Hasil Uji Coba 3

\begin{tabular}{lc}
\hline \hline Parameter & Modus \\
\hline Kualitas detail arsiran & 3 \\
Kualitas arsiran dilihat dari beberapa sudut pandang & 3 \\
Kualitas arsiran dilihat dari beberapa arah pencahayaan & 2 \\
\hline \hline
\end{tabular}

Pada uji coba terakhir, responden diminta menilai hasil teknik Single-Pass Six-Way Blend dan teknik Threshold Scheme dari seluruh gambar visualisasi pada uji coba sebelumnya. Penilaian dari kedua teknik ditunjukkan pada Tabel 4.

Tabel 4.

Tabel Hasil Uji Coba 4

\begin{tabular}{lc}
\hline \hline Teknik Shader Sketsa Arsiran & Modus \\
\hline Teknik Single-Pass Six-Way Blend & 4 \\
Teknik Threshold Scheme & 3 \\
\hline \hline
\end{tabular}

\section{KESIMPULAN}

Dari hasil uji coba yang telah dilakukan terhadap pembuatan program shader sketsa arsiran dengan teknik Single-Pass Six-
Way Blend dan teknik Threshold Scheme dapat diambil kesimpulan sebagai berikut:

1) Perangkat lunak rendering sketsa arsiran pada obyek $3 \mathrm{D}$ telah dapat diimplementasikan menggunakan teknologi DirectX 9.0 dan IDE RenderMonkey 1.82 dengan Tonal Art Maps sebagai masukan untuk arsiran.

2) Terdapat dua teknik rendering sketsa arsiran yang diaplikasikan pada perangkat lunak yang telah dibangun, yaitu teknik Single-Pass Six-Way Blend dan teknik Threshold Scheme. Adapun perbedaan dari kedua teknik ini adalah hasil visualisasi teknik pertama lebih tebal dan gelap dibandingkan visualisasi teknik kedua.

3) Berdasarkan hasil pengujian yang melibatkan 22 responden dengan menggunakan kuesioner, diperoleh hasil jika teknik Single-Pass Six-Way Blend dinilai lebih baik dibandingkan dengan teknik Threshold Scheme.

Pengembangan yang dapat dilakukan adalah melakukan pengembangan lebih lanjut terhadap penggunaan Tonal Art Maps (TAM) dan melakukan integrasi dengan modul pembangkitan pena dinamis agar hasil arsiran yang ditampilkan mirip dengan buatan tangan manusia.

\section{LAMPIRAN}

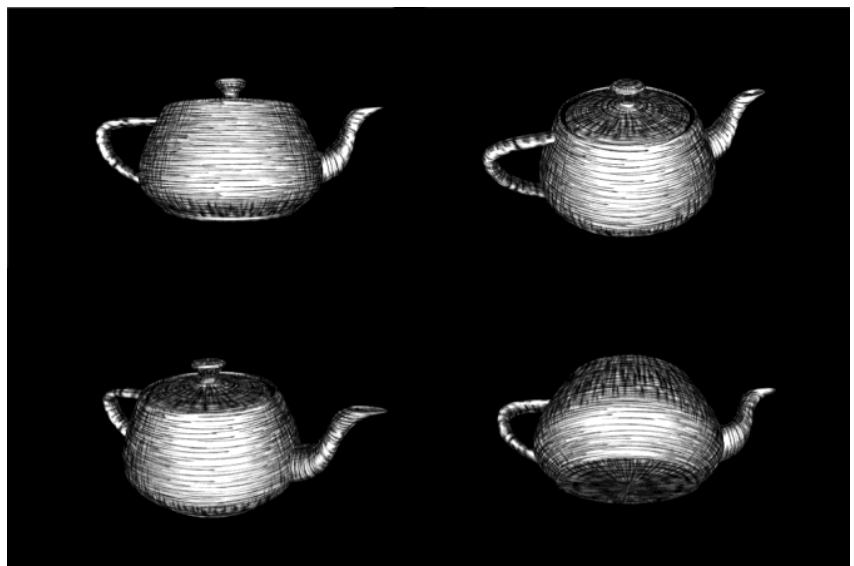

Gambar 3. Hasil Rendering Arsiran Kasar Teknik Single-Pass Six-Way Blend pada Obyek Teapot

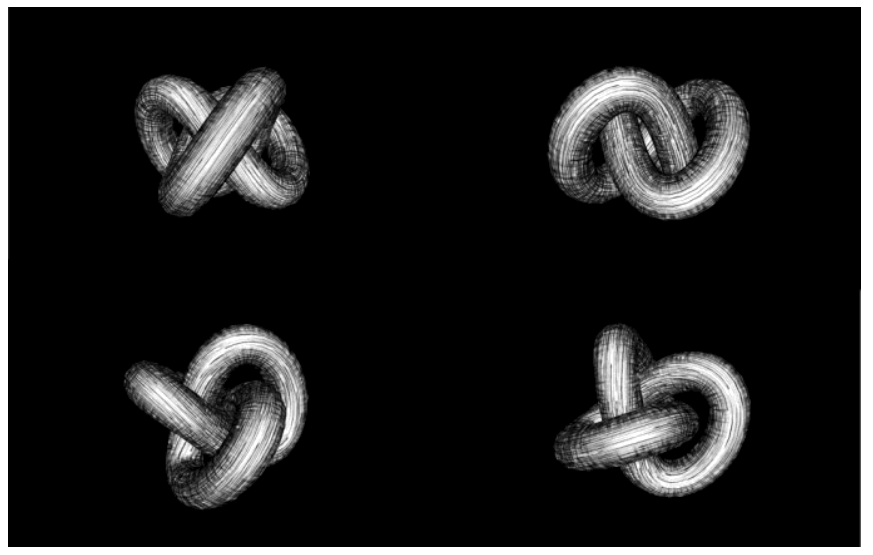

Gambar 4. Hasil Rendering Arsiran Kasar Teknik Single-Pass Six-Way Blend pada Obyek Torus 


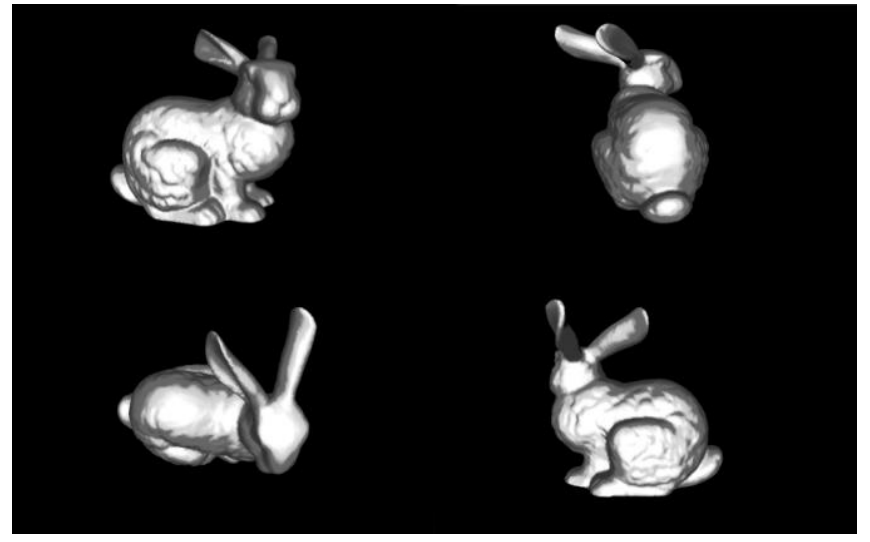

Gambar 5. Hasil Rendering Arsiran Halus Teknik Single-Pass Six-Way Blend pada Obyek Bunny

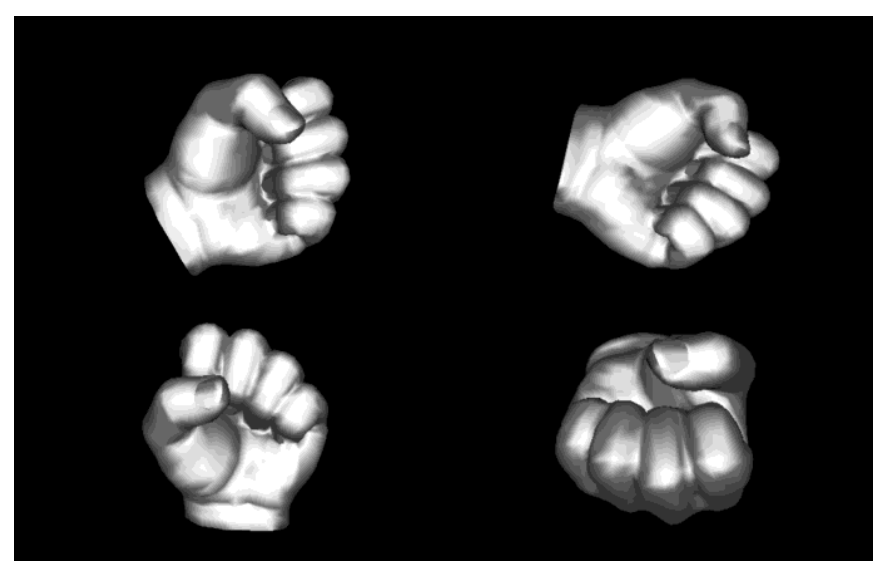

Gambar 6. Hasil Rendering Arsiran Halus Teknik Single-Pass Six-Way Blend pada Obyek Fist

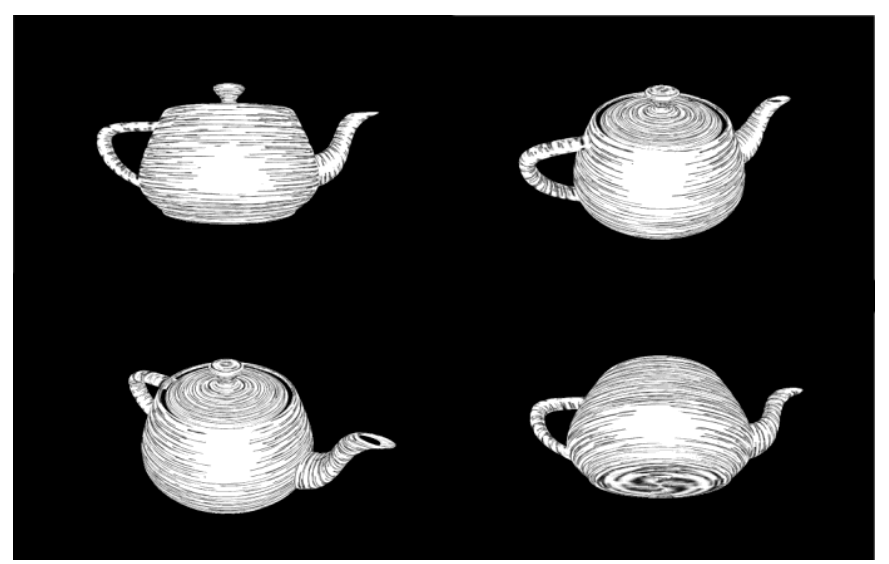

Gambar 7. Hasil Rendering Teknik Threshold Scheme pada Obyek Teapot

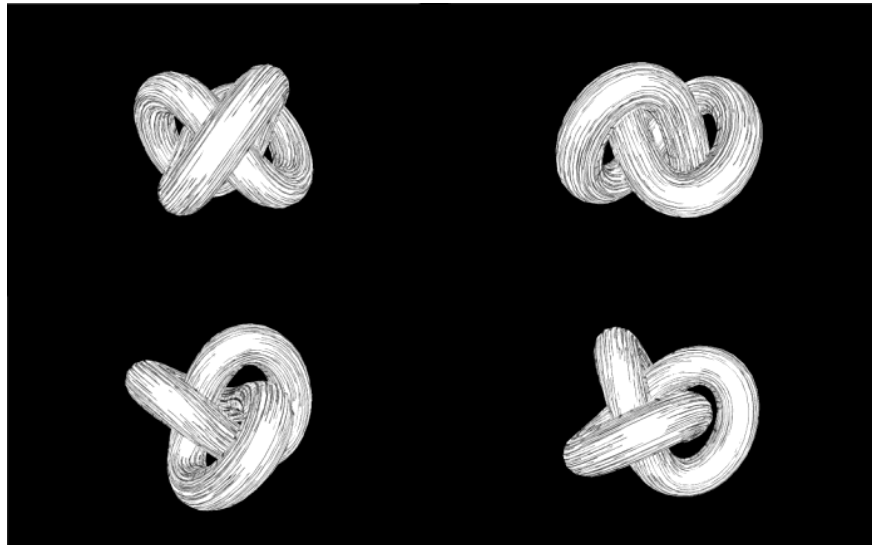

Gambar 8. Hasil Rendering Teknik Threshold Scheme pada Obyek Torus

\section{UCAPAN TERIMA KASIH}

Penulis D.S.T mengucapkan puji dan syukur kepada Tuhan YME yang telah melimpahkan berkat-Nya sehingga penulis dapat menyelesaikan penelitian dengan baik. Penulis juga menyampaikan ucapan terima kasih kepada Ibu Wijayanti Nurul K. dan Bapak Rully Soelaiman yang telah banyak membantu dan membimbing dalam menyelesaikan penelitian ini.

\section{DAFTAR PUSTAKA}

[1] G. Orbay and L. B. Kara, "Pencil-Like Sketch Rendering of 3D Scenes Using Trajectory Planning and Dynamic Tracking," Journal of Visual Languages and Computing, pp. 481-493, 2014.

[2] E. Praun, H. Hoppe, M. Webb and A. Finkelstein, "Real-Time Hatching," Proceedings of the 28th annual conference on Computer graphics and interactive techniques. ACM, 2001.

[3] M. Webb, E. Praun, A. Finkelstein and H. Hoppe, "Fine Tone Control in Hardware Hatching," Proceedings of the 2nd international symposium on Non-photorealistic animation and rendering. ACM, 2002.

[4] W. F. Engel, Direct3D ShaderX : Vertex and Pixel Shader Tips and Tricks, Texas: Wordware Publishing, Inc., 2002.

[5] W. F. Engel, Shader X2 : Shader Programming Tips and Tricks with DirectX 9, Texas: Wordware Publishing, Inc., 2004.

[6] D.-Y. Chen, X.-P. Tian, Y.-T. Shen and M. Ouhyoung, "On Visual Similarity Based 3D Model Retrieval," Computer Graphics Forum (EUROGRAPHICS'03), vol. 22, pp. 223-232, 2003. 